\title{
Egy ezeréves házasság felbontása: Turócszentmárton 1918. október 31.
}

\author{
Popély Gyula*
}

\begin{abstract}
The end of a millennium-long marriage: Turócszentmárton, October 31, 1918. The birth of the Czechoslovakian state during the autumn of 1918 was related to several symbolic events and several, geographically distant locations. Such locations were Prague, Paris, Pittsburgh and Turócszentmárton. In the latter town, the Slovakian nation broke up their millennium-long marriage with the Hungarian state and solemnly announced that they wish to live within the forming Czechoslovakian state. Our paper presents the details on what happened in Turócszentmárton on October 30, and the morning after, following Milan Hodza's arrival.
\end{abstract}

Keywords: Great War (1914-1918), history of Central-Europe, birth of the First Czechoslovakian Republic, activity of Milan Hodza

\section{Bevezetés}

A csehszlovák állam 1918 őszén történő megszületése több szimbolikus eseményhez, és ezek több egymástól igen távollévő helyszínhez köthetők. Ilyen helyszínek voltak Prága, Párizs, Pittsburg és Turócszentmárton. Ez utóbbi városban október 30-án a szlovák nemzet felbontotta a magyar állammal közel ezer éven keresztül fent álló házasságát, majd ünnepélyesen kijelentette, hogy ezután az éppen megszülető csehszlovák állam keretei között kíván élni. Tanulmányunkban részletesen bemutatjuk, hogy mi történt Turócszentmártonban október 30-i napon, illetve mi történt Milan Hodza megérkezése után másnap reggel.

\section{A turócszentmártoni deklaráció születése 1: az előértekezlet}

A Nagy Háború utolsó hónapjaiban miközben a Masaryk-Beneš-féle emigráció egyre komolyabban haladt elöre azon az úton, mely az antanthatalmak általi elismerésükhöz vezetett, a szlovák politikai elit is a cselekvés útjára lépett. ${ }^{1}$ A szeptembertől titokban már szervezkedő szlovák vezető politikusok októberben már nyíltan is készek voltak megfogalmazni politikai követeléseiket, bár még csak kevesen remélték, hogy a szlovákok lakta Felvidék egyáltalán kiszakítható lesz az ezeréves Magyarország testéből. Egy szlovák politikai csúcsszerv - a Szlovák Nemzeti Tanács - létrehozása mindenképpen célszerünek

\footnotetext{
* Intézmény: Károli Gáspár Református Egyetem

${ }^{1}$ Az 1918 évi előzményeket lásd Popély Gyula 2010, 82-101.
} 
látszott. Erre meg is történtek az előkészületek. Matúš Dula, a Szlovák Nemzeti Párt elnöke körlevélben szólította fel az ismertebb szlovák vezetőket, hogy október 30-án jelenjenek meg Turócszentmártonban, ahol megalakítják a Szlovák Nemzeti Tanácsot, és a szlovák nemzet nevében valamilyen deklarációval is kilépnek a nyilvánosság elé. ${ }^{2}$

Az 1918. október 30-ai értekezletre összesereglett szlovák vezetők azonban fölöttébb tájékozatlanok voltak. Friss külföldi információkkal alig rendelkeztek, és még a Csehszlovák Nemzeti Bizottság két nappal azelőtti - 1918. október 28. - prágai függetlenségi nyilatkozatáról sem volt tudomásuk.

1918. október 30-án délelőtt a turócsszentmártoni Tátra Bank épületében bizalmas előértekezletre került sor. A bennfentesebbek itt vitatták meg a délutáni ünnepélyes ülés részleteit. Összeállították a húszfőnyire tervezett Szlovák Nemzeti Tanács névsorát, továbbá hosszas mérlegelés után eldöntötték, hogy a három politikai deklarációtervezet közül melyiket terjesszék a délutáni értekezlet elé.

Az előértekezlet résztvevőit nagymértékben befolyásolta Ivan Dérer állásfoglalása a nyilvánosságra hozandó deklaráció szövegével kapcsolatban. Dérer ugyanis néhány nappal azelőtt - 1918. október 25-én - Milan Hodžával és Kornel Stodolával együtt részt vett a Prágából Svájcba utazó cseh delegáció értekezletén. A Kramář vezette cseh küldöttség azt üzente a szlovákoknak, hogy egyelőre ne kötelezzék el magukat visszavonhatatlanul a független csehszlovák állam mellett, ugyanis még mindig nem voltak biztosak abban, vajon Észak-Magyarország tót többségü vármegyéi valóban egyesíthetők lesznek-e a cseh történelmi tartományokkal. ${ }^{3}$

Az előértekezleten részt vevő szlovák vezetők Dérerre hallgatva igyekeztek józanul mérlegelni a fejleményeket. Az előterjesztett deklaráció-tervezetek közül is a mérsékeltebben fogalmazó Samuel Zoch elaborátumát fogadták el, és terjesztették a délutáni nagygyülés elé. A Zoch-féle tervezet deklarálta ugyan a „cseh-szlovák nemzet magyarországi ága” számára az önrendelkezés igényét, de nem emlegette a szlovákok elszakadási szándékát, illetve ügyesen megkerülte ezt a kérdést.

Egy másik tervezet szerzője és beterjesztője Emil Stodola volt. Ez már egyértelmüen a csehekkel való államjogi egyesülés és a csehszlovák állam létrehozása mellett tört lándzsát: „, A Szlovák Nemzeti Tanács a Wilson és Andrássy által elfogadott elvek és feltételek alapján a szlovák nemzet nevében kijelenti, hogy csatlakozik a testvéri cseh nemzethez, és vele együtt létrehozza a független, önálló cseh-szlovák államot” szögezte le teljes őszinteséggel a Stodola-féle deklarációtervezet. ${ }^{4}$

A továbbiakban azt is megindokolta, hogy miért nem igényel a szlovákok számára önálló, független államot, illetve, hogy miért a csehekkel és nem a magyarokkal képzeli el a további együttélést. „,Azért, mert kicsi, szegény és kevésbé müvelt nemzet vagyunk. Nekünk egy erösebb nemzetre kell támaszkodnunk, ez pedig csak a testvéri cseh nemzet lehet, amely erös, gazdag és müvelt. Mellette mi is megerösödünk, meggazdagodunk és kimüvelödünk. A magyarokkal nem élhetünk együtt, mivel mellettük nem találjuk meg szabadságunk, függetlenségünk, gazdasági és müveltségi fejlődésünk feltételeit. (...) ",5

Az egész deklarációtervezet vezérmotívumát Stodola a következő mondatokba sürítve fogalmazta meg: „A csehek mindig a mi testvéreink voltak, velük együtt akarunk

\footnotetext{
${ }^{2}$ Krajčovičová, Natállia 1969, 179.

${ }^{3}$ Hronský, Marián 1998, 44-46.

${ }^{4}$ Emil Stodola 1923, 1-2.

${ }^{5}$ Stodola 1923, uo.
} 
élni. A magyarok mindig idegeneknek tartottak bennünket, és mi az ő számukra továbbra is csak idegenek maradnánk. ${ }^{6}$

Emil Stodola idézett javaslatát, amely világosan kimondta a Magyarországtól való elszakadás, illetve a csehekkel való egyesülés tényét, a turócszentmártoni előértekezlet résztvevői - nem tudva semmit az október 28-i prágai eseményekről - túl merésznek tartották, ezért inkább az óvatosabban fogalmazó Samuel Zoch tervezetét fogadták el.

\section{A turócszentmártoni deklaráció születése 2: A délutáni értekezlet}

A délutáni órákban került sor a turócszentmártoni Tátra Bank nagytermében az ünnepélyes nagygyülésre, amelyen kb. 200 ember vett részt. ${ }^{7}$ A megjelentek egyhangúlag megszavazták a Szlovák Nemzeti Tanács megalakítását, amelybe változtatás nélkül bekerült mind a húsz, a délelőtti bizalmas előértekezleten kijelölt szlovák nemzetiségi politikus. Az így megalakított Szlovák Nemzeti Tanács a következő személyekből állt össze:

- Ludovít Bazovský,

- Method Bella,

- Pavel Blaho,

- Jozef Bránecký,

- Matúš Dula,

- Andrej Hlinka,

- Adolf Horváth,

- Ferdiš Juriga,

- Cyril Kresák,

- Emanuel Lehocký,

- Ján Maršalko,

- Vladimír Makovický,

- Karel Medvecký,

- Ján Ružiak,

- L'udovít Šimko,

- Vavro Šrobár,

- Emil Stodola,

- Kornél Stodola,

- Ján Vanovič

- Milan Žuffa.

A Szlovák Nemzeti Tanács elnökévé Matúš Dulát, a Szlovák Nemzeti Párt elnökét választották meg. ${ }^{8}$ A Szlovák Nemzeti Tanács létrehozása után az egybegyültek elfogadták a Samuel Zoch modori evangélikus lelkész által összeállított nemzeti deklarációt, amely önrendelkezést követelt a „,cseh-szlovák nemzet magyarországi ága”, azaz a felvidéki szlovákok számára, bár azok esetleges elszakadási szándékáról mélyen hallgatott. Az elfogadott nyilatkozat így formálisan még tiszteletben tartotta Magyarország integritásának elvét, persze nem tett semmilyen kötelező hüségnyilatkozatot a magyar haza felé sem.

\footnotetext{
${ }^{6}$ Stodola 1923, uo.

${ }^{7}$ A résztvevők listáját közli Szviezsényi Zoltán 1921, 75-76.

${ }^{8}$ Holotík, Ludovít 1979, 405-407.
} 


\section{A turócszentmártoni deklaráció születése 3: A délutáni értekezlet után}

Csakhogy másnap - 1918. október 31-én -, amikor a Szlovák Nemzeti Párt lapja, a Národnie Noviny nyilvánosságra hozta a deklarációt, az „némileg” módosított szöveggel jelent meg. Ez a változtatás egészen más hangsúlyt adott az események további folyásának. Joggal merül fel a kérdés: hogyan került sor a módosításra?

A módosítás előidézője Milan Hodža volt, aki 1918. október 30-án az esti órákban érkezett meg Budapestről Turócszentmártonba. A tekintélyes szlovák politikai vezetőnek minősülő Hodža fantasztikus új hírekkel kápráztatta el az est folyamán még a városban tartózkodó szlovák vezetőket. Elújságolta, hogy Budapest a teljes felfordulás küszöbén áll, az antanthatalmak elismerték a csehszlovák emigrációs kormányt a „,csehszlovák nemzet” egyedüli reprezentánsának, ${ }^{9}$ sőt két nappal azelött, 1918. október 28-án Prágában a Csehszlovák Nemzeti Bizottság már ki is kiáltotta a független Csehszlovák Köztársaságot. ${ }^{10}$

Mindezen események miatt Hodža azt javasolta, hogy változtassák meg a délutáni órákban már elfogadott deklaráció szövegét, hogy azt így szinkronba hozhassák az események folyásával. A szükségesnek vélt módosításokat maga az agilis Hodža végezte el, az alábbi módon:

- az első bekezdés végéről törölte azt a mondatot, amelyben a magyarországi szlovákok önálló képviseletet követelnek az összehívandó békekonferencián. Érvelése szerint erre a képviseletre csakis az antanthatalmak által már elismert csehszlovák kormány lesz illetékes.

- a deklaráció 2. pontját pedig, amely eredetileg csak egyetlen mondatban, tömören és minden indoklás nélkül követelte az önrendelkezési jogot, megtoldotta még egy mondattal: „Ezen elv alapján egyetértésünket fejezzük ki azzal az újonnan létrehozott nemzetközi jogi állapottal, amelyet 1918. október 18-án Wilson elnök fogalmazott meg, és amelyet 1918. október 27-én az osztrák-magyar külügyminiszter elismert."

Hodža beavatkozását a már jóváhagyott szövegbe mind Matúš Dula, a Szlovák Nemzeti Tanács elnöke, mind pedig Samuel Zoch, a deklaráció eredeti szövegének összeállítója elfogadták. ${ }^{11}$ Bár az is tény, hogy sem a megválasztott húsztagú nemzeti csúcsszerv, sem szélesebb szlovák nagygyülés nem tárgyalhatta meg és nem hagyhatta jóvá ezeket a változtatásokat. Persze, az események folyását ez egyáltalán nem befolyásolta, mivel a szlovák kérdés nemzetközi vonatkozásban ekkor már teljes egészében a cseh politikai törekvések függvényének számított.

Mind azt már jeleztük a turócszentmártoni deklaráció Milan Hodža által módosított teljes szövegét, másnap - október 31-én - a Národnie Noviny különkiadása hozta nyilvánosságra (lásd tanulmányunk Mellékletét).

A szöveget eredetileg 2 fö Dula és Medvecký írta alám. De aztán az „aláírók” serege később 93 före szaporodott. Korabeli politikusok és a kérdéssel foglalkozó történészek ${ }^{12}$ az egész akció komoly szépséghibájának tartották, hogy az aláírók túlnyomó többsége - pontosan a 93 főből 72 személy - Turóc, valamint Liptó

\footnotetext{
${ }^{9}$ A csehszlovák emigráció tevékenységéről lásd Gulyás László 2008/a, 41-96.; Gulyás László 2008/b, $43-84$. Az emigráció programjának formálódásáról lásd Gulyás László 1996, 103-108.; Gulyás László 2000, 35-50.

${ }^{10}$ Erről lásd Gulyás László 2018, 52-58.

${ }^{11}$ Samuel Zoch 1923, 2.

${ }^{12}$ Steier Lajos 1928, 163-169.
} 
vármegyékből verbuválódott. Pusztán Turócszentmártonból 38-an írták alá a deklarációt. Ez azonban érthető is, elvégre a helybéliek voltak leginkább „kéznél”. A szlovákok által lakott további felvidéki vármegyéket senki sem képviselte. Ez a tény a későbbiek folyamán meglehetősen zavaró tényezővé vált a szlovák politikai életben.

\section{MELLÉKLET: a deklaráció szövege}

\section{A tót nemzet deklarációja}

Valamennyi szlovák politikai párt képviselői, akik 1918. október 30-án Turócszentmártonban összegyültek, és akik az egységes cseh-szlovák nemzet szlovák ágának Nemzeti Tanácsába tömörültek, ragaszkodnak a nemzetek egész világ által elfogadott önrendelkezési jogának elvéhez. A Nemzeti Tanács kijelenti, hogy a történelmi Magyarország határain belül élő cseh-szlovák nemzet nevében egyedül jogosult szólni és cselekedni.

Nem jogosult erre a magyar kormány, amely hosszú évtizedek alatt nem látott fontosabb feladatot, mint hogy elnyomjon mindent, ami szlovák, nem épitett és nem engedélyezett nemzetünknek egyetlen iskolát sem, nem engedte, hogy szlovák emberek bejussanak a közhivatalokba és a közigazgatásba, népünket pedig anyagilag tönkretette, középkori feudális rendszerével és politikájával kizsákmányolta.

Nem jogosultak arra, hogy a szlovák nép nevében szóljanak azok az úgynevezett képviselötestületek sem, amelyek a nemzet akaratának érvényesülését megakadályozó szükre szabott választójog alapján jöttek létre, és olyan személyekböl állnak, akik a törvény rendelkezése ellenére sem engedték a bizottságokban egyetlen szlovák szó elhangzását a tiszta szlovák vármegyékben sem.

Nem jogosultak erre olyan népgyülések sem, amelyek idegen eröszak nyomására hoznak határozatot.

Szlovákiában tehát a szlovák nemzet nevében egyedül a Szlovák Nemzeti Tanács jogosult szólni.

A Magyarország határain belül lakó cseh-szlovák Nemzeti Tanácsa kinyilatkoztatja:

1. A szlovák nemzet mind nyelvi, mind kulturális-történelmi szempontból az egységes cseh-szlovák nemzet része. Minden kulturális harcban, melyet a cseh nemzet folytatott, és amely ismertté tette az egész világon, részt vett a szlovák ág is.

2. E cseh-szlovák nemzet számára követeljük mi is a korlátlan önrendelkezés jogot a teljes függetlenség alapján. Ezen elv alapján egyetértésünket fejezzük ki azzal az újonnan létrehozott nemzetközi jogi állapottal, amelyet 1918. október 18-án Wilson elnök fogalmazott meg, és amelyet 1918. október 27-én az osztrák-magyar külügyminiszter elismert.

3. Követeljük a béke azonnali megkötését, mégpedig egyetemes keresztény emberi elvek alapján, hogy olyan béke legyen, mely a nemzetközi jog garanciájával lehetetlenné teszi a további háborút és fegyverkezést.

Meg vagyunk gyözödve arról, hogy a mi törekvö és tehetséges szlovák nemzetünk, amely a hallatlan elnyomás ellenére a nemzeti kultúra ilyen szintjére jutott, nem záratik ki a béke áldásából és a nemzetek közösségéböl, és neki is megadatik, hogy a maga módján fejlödhessen, és erejéhez mérten hozzájárulhasson az emberség általános haladásához. 


\author{
A Szlovák Nemzeti Tanács ülésén, \\ Turóccszentmártonban, 1918. október 30-án. \\ Karol Medveckýs. k., a Szlovák Nemzeti Tanács titkára \\ Matúš Dula s. k., a Szlovák Nemzeti Tanács elnöke"45
}

\title{
Felhasznált irodalom
}

Gulyás László 1996, Egy sikeres emigráció anatómiája. Edvard Benes 1914-1918. AETAS 1996/2-3. szám, 103-108. old.

Gulyás László 2000, „Zúzzátok szét Ausztria-Magyarországot!” Avagy a MasarykBenes-féle csehszlovák emigráció érvrendszerének első szintézise. LIMES 2000/4. szám, 35-50. old.

Gulyás László 2008/a, Edvard Beneš. Közép-Európa koncepciók és a valóság. Máriabesnyő-Gödöllö: Attraktor Kiadó.

Gulyás László 2008/b, Beneš statesman or charlatan? The plans and the reality 19081948. Toronto-Buffalo: Corvinus Publishing.

Gulyás László 2018, A csehszlovák állam születése. BBC History 2018/október, 52-58. old.

Holotík, L'udovít 1979, Sociálne a národné hnutie na Slovensku od Októbrovej revolúcie do vzniku československého štátu (dokumenty). Bratislava, 405-407. old.

Hronský, Marián 1998, Boj o Slovensko a Trianon 1918-1920, Bratislava. 44-46. old.

Krajčovičová, Natállia 1969, Slovenská národná rada roku 1918. In: Historický časopis, 1969. 2. sz., 179. old.

Popély Gyula 2010, Felvidék 1914-1920. Magyar Napló. Budapest.

Stodola, Emil 1923, O turčiansko-sv.-martinskej deklarácii. Národnie noviny, 1923. március 11., 1-2. old.

Steier Lajos 1928, A tót deklaráció. Magyar Szemle 1928/február, 163-169. old.

Szviezsényi Zoltán 1921, Hogyan veszett el a Felvidék? Budapest: Franklin Társulat. 75-76. old.

Zoch, Samuel 1923, Martinská deklarácia pofalšovaná. Ludové nonviny, 1923. február 11., 2. old. 